\title{
INSTITUTIONAL INTERACTION \\ AND POLITICAL CHOICE IN A TRANSITIONAL SOCIETY. WHAT ROLE FOR THE SOCIAL SCIENCES?
}

\section{Liliya Yakovleva, Denys Yakovlev}

\section{INTRODUCTION}

In post-communist Ukraine, which is transiting from Soviet totalitarianism to democracy, the conflict between the new rules of the game and the old institutions is escalating (Matsiyevsky Y. $(2018)^{1}$, Stefes C. $(2006)^{2}$, Ghia N., Cenusa D., Minakov M. $\left.(2017)^{3}\right)$. The society needs changes. The Revolution of Dignity, as well as the results of the electoral campaigns of 2014 and 2019, shows the articulated powerful social intentions for the continuation of democratic transit and the creation of new rules and institutions.

"Ukraine has changed the political landscape: the vast majority of political actors publicly call themselves democrats, almost all political parties are placed under the democratic codes. Democratization involves looking for mechanisms of one of the main tasks solving: rational actions transformation of the individual and collective political actors to the collective rational action with the satisfaction of public interest" .

Instead, the post-Soviet institutions are resisting change. They are ready to throw the baby out with the bathwater to maintain power and ownership. Media manipulation, speculation on the subject of armed conflict, deprofessionalisation of government and ignoring social policy are all used to compromise democratic reforms. All this requires a study of institutional interaction through the lens of political choice theory. One of the factors that hinder this transit is the lack of a tradition of institutional interaction. Indeed, in the Soviet era there were no branches of power independent from the party leadership of the CPSU - legislative, executive, judicial, etc., and therefore their legal and public interaction.

${ }^{1}$ Matsiyevsky Y. (2018) Revolution without Regime Change: The Evidence from the PostEuromaidan Ukraine. Communist and Post-Communist Studies, vol. 51 no 4, pp. 349-359.

${ }^{2}$ Stefes C. H. (2006) Understanding Post-Soviet Transitions. London: Palgrave Macmillan.

${ }^{3}$ Ghia N., Cenusa D., Minakov M. (2017) Democracy and its Deficits: The Way of Georgia, Moldova and Ukraine towards Becoming European-Style Democracies. Center for European Policy Studies policy papers. Retrieved from: http://www.3dcftas.eu/publications/other/ democracy-and-its-deficitsway-georgia- moldova-and-ukraine-towards-becoming

${ }^{4}$ Yakovlev D. (2015) Democracy "On the March": Rethinking the Role of Propaganda and the "Party of Power" under Armed Threat. Proceedings of the Scope: science of politics - International Interdisciplinary Conference of Political Research (Bucharest, May 8-9, 2015), University of Bucharest 
In the search of an answer to the problem of Ukrainian ambivalence discussed by M. Riabchuk (1992, 2002, 2015) ${ }^{5}$ et al. (Walker E. W. (2014)) ${ }^{6}$, researchers have repeatedly addressed the issues of identity (Kuzio T. $(1996))^{7}$, linguistic diversity (Kulyk V. (2011) $)^{8}$, external challenges (Mitrokhin N. (2015) ${ }^{9}$, (Kuzio T.(2017) $)^{10}$.

It is time to look at the phenomenon of political choice and institutional interaction. The method of choice is the key to solving the problem of ambivalence, which allows avoiding two disadvantages of behaviour of the late Soviet and Ukrainian elites: 1) escape from choice (Yakovlev D. (2015) $)^{11}$ and 2) traps of "hybridity".

The article is devoted to the role of the social sciences in the choice of the optimal model of institutional interaction. The social sciences should help individuals make choices while collaborating with other people, institutions or organizations in politics and economics, education and culture. To accomplish this mission, we create models, offer dilemmas (alternatives) of choosing, study history, and predict the future, trying to assess the risks and consequences of one or another choice.

The existing inter-institutional interaction studies do not analyse the specificity of post-communist transit conditions (Young A. (2017)) $)^{12}$. The papers devoted to this transit and political choice increasingly underestimate the importance of institutional interaction (Clement J. $(2016)^{13}$. Our objective

\footnotetext{
${ }^{5}$ Riabchuk M. (1992) “Two Ukraines?”. East European Reporter, vol. 5, no. 4, pp. 18-22; Riabchuk M. (2002) Ukraine: One State, Two Countries. Transit Online. Retrieved from: http://www.eurozine.com/pdf/2002-09-16-riabchuk-en.pdf;Riabchuk M. (2015) “Two Ukraine's' Reconsidered" The End of Ukrainian Ambivalence? Studies in Ethnicity and Nationalism, vol. 15, no. 1, pp. 138-156.

${ }^{6}$ Walker E.W. (2014) "Ukraine: Divided Nation, Divided State. Eurasian Geopolitics. Retrieved from: http://eurasiangeopolitics.com/2014/03/14/ukraine-divided-nation-divided-state

${ }^{7}$ Kuzio T. (1996) "National Identity in Independent Ukraine: An Identity in Transition. Nationalism and Ethnic Politics, vol. 2 no. 4, pp. 582-608.

${ }^{8}$ Kulyk V. (2011) "Language Identity, Linguistic Diversity, and Political Cleavages: Evidence from Ukraine." Nations and Nationalism, vol. 17 no. 3, pp. 627-648.

${ }_{9}$ Mitrokhin N. (2015) "Infiltration, Instruction, Invasion: Russia's War in the Donbass". Journal of Soviet and Post-Soviet Politics and Society, vol. 1, no. 1, pp. 219-249

${ }^{10}$ Kuzio T. (2017) Putin's war against Ukraine. Revolution, nationalism, and Crime. Toronto: Association with the Chair of Ukrainian Studies, University of Toronto

11 Yakovlev D. (2015) Political choice of Ukraine: alternatives to the Grand Duke and restriction of the last secretary general. Proceedings of the Social and political configurations of Modernity: Political Power in Ukraine and in the World: Materials of the 4th International Scientific and Practical Conference (Ukraine Kyiv, June 3-4, 2015) (eds G. Derlugyan, A.A. Melnichenko, P.V. Kutuev, A. A. Migalush), Kyiv: Talcom, pp. 39-41.

12 Young A. (2017) Democratic Dialogue and the Constitution. New York: Oxford University Press

${ }^{13}$ Clement J. (2016). Electoral rule choice in transitional economies. Journal of Institutional Economics, vol. 12, no. 4, pp. 895-919.
} 
in this article is as follows. Firstly, to identify the dilemmas of political choice research in the conditions of post-communist transit. Only the social sciences can offer an interdisciplinary approach to post-communist transit that takes into account the particularities of individual choice in politics (electoral choice) and religion, economics (profit maximization) and culture. Secondly, to outline the contours of the theory of choice of institutional interaction in Ukraine (between the institutions of "peace" and "war", authoritarian and democratic, public and shadow institutions, etc.). The conclusions identify the need for a multidisciplinary approach to the problem of choosing the optimal model of institutional interaction and the rejection of a "hybrid" in favour of a dialectical "synthesis".

\section{The "Homo eligit" Model and the Dilemmas of Political Choice Research}

The process of political and economic transit of Ukraine to democracy and market economy takes place in the conditions of building the information society, multipolarity of international relations under the influence of many factors. It becomes evident that none of the global players (as far as Ukraine's interests are concerned, i.e. the EU, the US, the Russian Federation) is able to impose a transit model on Ukrainian society. In this sense, the age of empires that were capable of keeping large territories under total control is over. It is obvious that some empires, like repressive and big multinational states, are trying to revive; so far, such attempts have failed (Motyl A. J. (2001)) ${ }^{14}$. In Ukraine, which is at the crossroads of global interests, information flows, different values, different policies, there is a chaos of voices, thoughts and meanings.

In fact, as at the beginning of the twentieth century, we have implemented the "Huliaipole" model, however, in symbolic and informational terms. What should be done to turn the 21 st century into a ravaged century for Ukraine? (Conquest R. (2001)) ${ }^{15}$. Almost the only way to make decisions in such circumstances is to make daily rational choices. If the Ukrainian homo politicus wants to be successful in the plural world, it has to become homo eligit - the person of choice.

The mission of the social sciences is to determine "What?", "Why?" and "How?" individuals in the Ukrainian society, which has been deprived of the possibility of choice in various "empires" for centuries, elect.

\footnotetext{
${ }^{14}$ Motyl A. J. (2001). Imperial ends: the decay, collapse, and revival of empires. New York: Columbia University Press

${ }^{15}$ Conquest R. (2001). Reflections on a ravaged century. New York-London: WW Norton \& Company
} 
It is preferable to start with the historical experience of the collapse of the Soviet empire, the crisis of the project of homo soveticus (the "Soviet man"). Particular emphasis should be placed on the importance of overcoming indoctrination in secondary and higher education, the source of which is the ideologization of all social interactions in the USSR. Indoctrination not only hinders critical thinking (which is undoubtedly one of the competences of homo eligit) and is a system of imposing a certain ideology but also actualizes the problems of collective memory, identity and modes of truth. Indoctrination “... involves exposing the ideologization of education, the dangers of recapitalizing choice, and deconstructing the canon through demonstrating historical alternatives ... of choice" (Kroytor A., Yakovlev D., Aleksentseva-Timchenko K. (2019)) ${ }^{16}$. Indoctrination, according to J. Jay, means, first of all, the following: 1) the source of information is the state; 2 ) the absence of alternatives regarding the government position of views and versions of events (Jay J. (2019)) $)^{17}$.

Overcoming indoctrination is the first step to making a rational choice for an individual. The second step is to critically rethink the Soviet experience. The awareness of the "escape from choice" that characterized the actions of the Soviet elites during the rule of L. Brezhnev (the era of "stagnation") and M. Gorbachev (the era of half-hearted reforms of "perestroika" and "glasnost") is necessary. The political situation has changed globally. It is becoming increasingly apparent that the efforts to mitigate the existing contradictions through the formation of the "pseudo-consensus" to which the Ukrainian elites got accustomed in the late 1980s did not save them in the early third decade of the 21 st century. Creating ideological, political and economic "hybrids" is a mistake in terms of both politics and public policy. On the contrary, formulating real alternatives and deciding what is best for society is the only way forward. Naturally, one of the main dilemmas of choice "... is to solve the problem of choosing an optimal course of behaviour in the conditions of uncertainty: "To choose or not to choose?" An illustration of the first way "Choose!" is the choice of religion by Prince Vladimir. According to the chronicles, this figure not only chose the monotheistic religion (Christianity of the Byzantine rite) but also imposed his own dictatorial decision in a way that influenced the life of Europe for many

\footnotetext{
${ }^{16}$ Kroytor A., Yakovlev D., Aleksentseva-Timchenko K. (2019) 'Apostles' of indoctrination: ideological peculiarities of representation of religious choice in the secondary education (based on analysis of expert interviews) Ideology and Politics, no. 2 (13), pp. 127-146. Retrieved from: https://ideopol.org/wpcontent/uploads/2019/12/

${ }^{17}$ Jay J. (2019). Education or Indoctrination. Discerning the Difference. Free Book site. Retrieved from: https://islidedocs.com/document/education-or-indoctrination-discerning-thedifferencefree-book
} 
centuries. To illustrate the alternative "Not to choose!" it is worth mentioning the activity of the last USSR General Secretary M.Gorbachev. Despite the large-scale (as for the Communist leader) reforms, he failed to choose between the Soviet model and democracy. Instead, in order to combine them, he proposed a semi-reform project - "perestroika" (Yakovlev D.V. (2016)) ${ }^{18}$.

Thirdly, we need to be very careful about the recommendations of our Western partners and carefully choose the ones that are "suitable" for the Ukrainian situation. It is likely that modern developed countries have simply forgotten how they became consolidated democracies, and the way a market economy emerged and modernization began (De Soto, H. (2000) ${ }^{19}$. Thus, it is appropriate to throw a bridge to the topic of institutional interaction. At the stage of market relations, the start of modernization and competition, private ownership has become the most important institution, and the main task of the elites was not only the fight against corruption or the emphasis on cultural or national differences but also the legalization and legal protection of private property (Gilbert, A. (2002)) $)^{20}$.

Last but not least, political choice needs to take into account the peculiarities of post-communist societies and the overcoming of pathologies that have emerged in the process of transition. Diagnosing them is a direct task of the social sciences. E. Golovakha singles out the following social pathologies of post-communist societies: the ambivalence of political consciousness, the combination of conformism and nihilism in the attitudes of individuals to reality, deprofessionalization, erosion of the criteria of status and prestige in social interaction, deactualization of values (Golovakha E., Panina N., Vorona V. (2000) $)^{21}$.

They cause the consequences in the attitudes of citizens to politics, namely - the trust in populist manipulations, paternalism, and the tendency to moralising.

Having identified the role of the social sciences in formulating sound alternatives to rational choice and overcoming indoctrination, critical rethinking of external recommendations, and diagnosing social pathologies, we should turn directly to the analysis of a "situation of choice". Imagining

${ }^{18}$ Yakovlev D.V. (2016) Dylemy vyboru. [Dilemmas of choice]. Young scientist, vol. 7, no. 34, pp. 503-508. Retrieved from: http://molodyvcheny.in.ua/fi les/journal/2016/7/120.pdf

${ }^{19}$ De Soto H. (2000). The mystery of capital: Why capitalism triumphs in the West and fails everywhere else. Bantam Press

${ }^{20}$ Gilbert A. (2002) On the mystery of capital and myths of Hernando de Soto: what difference does the legal title make? International Development Planning Review, № 24 (1), pp. $1-19$.

${ }^{21}$ Golovakha E., Panina N., Vorona V. (Eds) (2000) Sociology in Ukraine. Selected Works Published During 90-th. Kiev: Institute of Sociology 
and presenting individual behaviour as a transition from one choice (a "situation of choice") to another one is difficult intellectual work that requires the identification of alternatives and their "weighing", evaluation according to many factors. Rather, the interpretation of a political decision as a consequence of choice enables the social sciences to explain its causes and consequences. As G. Hodgson notes, “... a principal goal of any science is explanation. Explanation causes suggestion of cause and effect relationships. Without a presumption of causality, there can be no convincing scientific explanation for any phenomenon" 22 .

It is much more difficult to determine the political course of the country through the lens of an election series with one of many complex and ambiguous alternatives. We use the artistic image of a "Knight at the Crossroads", known since childhood. Is it possible to use the metaphor of a "Country at the Crossroads"? Thus, taking into account the following factors: "geographical location between regional and global centres of influence, domestic and foreign policy challenges, constitutional reversals, economic situation (most notably - a hybrid combination of private and state ownership), etc. In fact, in every social area, the situation of choice can be observed... political choice is not limited to alternatives to the return to the Soviet "bright" past or the desire for the democratic future" ${ }^{23}$. Reflection on the democratization of institutional interaction based on an analysis of the "situation of choice" is complicated by the process of demodernization in the post-Soviet space $^{24}$.

In the process of modernization that Western democracies underwent, the choice has become a routine. The rules of political and economic interaction have become established and recognized. With modernization, the daily choice of an individual, as well as the choice of the political course of a country, is based on certain interests and values, norms and rules that have remained unchanged for decades. The modernization of society immensely facilitates the choice of an individual. After all, most important decisions have already been made, "great narratives" have been created and legitimized: "Modernization has created a world in which it seems that the "Great Choice" remained in history: the consumer chooses products in the supermarket every day, the viewer chooses television channels, and the bureaucrat, though he

\footnotetext{
${ }^{22}$ Hodgson G. (2001). How Economics Forgot History. London: Routledge.

${ }^{23}$ Yakovlev D.V. (2017) Ideja vyboru [The idea of choice ]. Proceedings of the Reghionaljna polityka : istorija, polityko-pravovi zasady, arkhitektura, urbanistyka: Tretja mizhnarnarodna naukovo-praktychna konferancija (Ukraine, Kyiv, November 22-23, 2017), Kyiv: Kyjiv. nac. un-t budivn. i arkhit-ry ta in, vol. 1, pp. 43-48.

${ }^{24}$ Rabkin Y., Minakov M. (eds.) (2018). Demodernization: A Future in the Past. Stuttgart: Verlag
} 
makes a crucial political choice every day, is opposed to political leaders who led European nations in the past. From heroic, dramatic or comedic act, the choice has become a routine affair" 25 .

On the other hand, in the process of demodernization, the destruction of habitual lifestyle and rethinking of values, interests and norms takes place (Individual and collective ones). It should be emphasized that in the process of demodernization the role of the social sciences is to rationalize the choice: to define its social framework, political conditions and alternatives.

The theory of political choice has "...formed a rather sceptical attitude to the theory of rational choice as it is presented in the model Homo ekonomicus. We tend to talk about choices based on the principle of bounded rationality. This allows taking a more balanced approach to understanding the principles of political choice: from electoral one to the choice of optimal constitutional and institutional policies. However, the main requirement of the idea of choice is alternativeness. The very logic of political choice in a democracy implies alternativeness: a political figure has to be chosen from among different candidates. Alternativeness means difference; in competitive elections, it is a competitive difference" 26 .

For instance, contemporary Ukrainian political politics has identified the following political choice dilemmas regarding institutional interaction: 1) Authoritarianism vs. Democracy; 2) Presidential vs. Parliamentary forms of government; 3) Proportional vs. Majority election models. Choosing the best institutional interaction model is impossible without addressing these global dilemmas. For more than twenty-nine years, Ukrainian political elites have been trying to make that choice, but have been limited to "hybrid" models: the parliamentary-presidential form of government, a mixed electoral system, democracy, and the remnants of Soviet authoritarianism. It is noticeable that a rational choice based on the consent of elites and society on these dilemmas should be constitutionally enshrined. Solving these dilemmas in favour of democracy, parliamentarism and the proportional electoral system has to be a prerequisite for effective institutional interaction: "Democratization involves seeking mechanisms for solving one of the main tasks: transforming rational

${ }^{25}$ Yakovlev D.V. (2015) Alea jacta est: vybir jak element socialjnoji vzajemodiji [Alea jacta est: choice as an element of modern interaction] Proceedings of the Priorytetni naprjamky rozvytku suspiljnykh nauk u 21 stolitti": materialy mizhnarodnoji naukovoji konferenciji (Ukraine, Kherson, February 27-28, 2015), Kherson: Gheljvetyka, pp. 155-159.

${ }^{26}$ Yakovlev D.V. (2017) Ideja vyboru [The idea of choice ]. Proceedings of the Reghionaljna polityka : istorija, polityko-pravovi zasady, arkhitektura, urbanistyka: Tretja mizhnarnarodna naukovo-praktychna konferancija (Ukraine, Kyiv, November 22-23, 2017), Kyiv: Kyjiv. nac. un-t budivn. i arkhit-ry ta in, vol. 1, pp. 43-48. 
actions of individual and collective political actors into a collective rational action to satisfy the public interest. Traditionally, the post-Soviet elite tries to avoid "either-or" choice, but Ukrainian political history knows many examples of when "confusion" has led to political crises, confrontation of branches of power and their irresponsibility ... In Ukraine, elections were conducted on proportional, majority and mixed bases. The main dilemma regarding the electoral model is the choice between a full-fledged representation and a structured parliament. According to the proportional system, the role and weight of political parties is increasing, which can gradually become an effective institution of political representation" 27 The situation of choice is an element of the research program that provides an appropriate picture of the world. Researchers rely on the model "Homo eligit", and their further steps depend on the choice of one of the alternatives. As a research program in the social sciences to form an optimal model of institutional interaction, the following alternatives are offered: 1) Individualism vs. Collectivism; 2) Action vs. Structure; 3) Hierarchy vs. Network; 4) Stability Vs. Conflict; 5) Rationality Vs. Irrationality ${ }^{28}$.

The first dilemma is fundamental, and the most heated discussions are held around it. L. Udehn points out that "...there have been many names used to designate the two camps and their respective doctrines. In the twentieth century two (or three) names have been selected as the most common. The battle has been increasingly waged in terms of methodological individualism, and its transmutations, versus methodological collectivism and/or holism... I believe the first view is more correct. Anyone the least acquainted with the social sciences knows that it matters which view you adopt in this matter. Methodological collectivists and holists do tend to ask different questions and provide different answers than do methodological individualists. There are important differences also within the two camps, but this is another matter. I also find it hard and a little bit odd to believe that the best minds in the history of social thought should really have engaged, and with so much energy, in something which turns out to be a sham battle. Didn't they notice?"29.

${ }^{27}$ Yakovlev D.V. (2017) Ideja vyboru [The idea of choice ]. Proceedings of the Reghionaljna polityka : istorija, polityko-pravovi zasady, arkhitektura, urbanistyka: Tretja mizhnarnarodna naukovo-praktychna konferancija (Ukraine, Kyiv, November 22-23, 2017), Kyiv: Kyjiv. nac. un-t budivn. i arkhit-ry ta in, vol. 1, pp. 43-48.

${ }^{28}$ Yakovlev D.V. (2016) Parlament na rozdorizhzhi: Rada jak instytut politychnogho vyboru [Parliament at the Crossroads: The Council as an Institute of Political Choice] Proceedings of the Parlamentsjki chytannja : 6-ta shhorichn. mizhnar. konfer. (Ukraine, Kyiv, November 18-19, 2016), Kyiv: FOP Zhorin R. V., pp. 12-17.

${ }^{29}$ Udehn L. (2002). The Changing Face of Methodological Individualism. Annual Review of Sociology, no. 28, pp. 479-507. Retrieved from: www.jstor.org/stable/3069250. (accessed online January 26, 2020). 
The theory of choice has both advantages and limitations. Basic assumptions include ideas about rational behaviour of an individual (which is not always the case), attempts to maximize benefits (exceptions are also possible here), attention to opportunistic behaviour, rents, transaction costs, etc. When it comes to the political choice of the optimal model of institutional interaction, it is necessary to determine the essence of "public interest". Political activity should not be aimed at serving the selfish interest of an actor or institute, but at serving the public good. The implementation of the model of "Homo eligit" is impossible if we still believe in the invisible hand of the market. On the contrary, the political choice theory makes it clear that democratic reforms are possible only under the conditions of proper planning, creation of political, legal and economic conditions for the rational construction of institutional interaction.

The prime example is the formation of an optimal model of institutional interactions.

\section{The Combinatorics of Choice: the Role of the Social sciences in Optimizing Institutional Interactions}

Institutional interaction is studied in terms of law and constitutional theory (Young A. (2017)) $)^{30}$, economics (Šimić Banović, R. (2015)) $)^{31}$ and public policy (Raišienė A. , Bilan S., Smalskys V., Gečienė J. (2019)) $)^{32}$.

J. Mark Ramseyer convincingly explains the link between political choice and the work of institutions: "First - and most basically - in modern democracies, politicians must work to compete in electoral markets or they do not stay politicians. As a result, there's a market constraint to politics. Second, because of this constraint, when constituents don't much care about an issue, rational politicians will likely trade their vote on it for a vote on something their constituents do care about. There's simply no such thing as a free vote. Last, institutions decisively shape the way voter preferences get mapped onto legislation. Often, the institutional structure of the electoral market itself determines what becomes law" (Ramseyer J. M. (1995)) ${ }^{33}$.

30 Young A. (2017) Democratic Dialogue and the Constitution. New York: Oxford University Press

${ }^{31}$ Šimić Banović, R. (2015). Institutional Interaction in the Business Environment: Eastern European Versus Western European Countries. Zbornik Pravnog fakulteta u Zagrebu, vol. 65, no. 3-4, pp. 439-480.

${ }^{32}$ Raišienè A. , Bilan S., Smalskys V., Gečienè J. (2019). Emerging changes in attitudes to inter-institutional collaboration: the case of organizations providing social services in communities. Administratie si Management Public, no.33, pp. 34-56.

${ }_{33}$ Ramseyer J. M. (1995) Public Choice. Coase-Sandor Institute for Law \& Economics Working Paper, no. 34. Retrieved from: https://chicagounbound.uchicago.edu/cgi/ viewcontent.cgi?article=1393\&context=law_and_economics 
Based on the theory of choice theory, the social sciences can offer a solution to the problem of optimal combinatorics of institutional interaction. The consideration of individual institutions is erroneous. The experience of post-communist reforms has convincingly demonstrated that the problem lies not in the creation of individual institutions, but in ensuring their effective interaction. This approach requires interdisciplinary research. The success of institutional interaction is hindered not only by political but above all by social and cultural factors: "In Central and Eastern Europe, institutional design seems to be highly influenced by the complex legacy. It has now been widely accepted that "no size fits all" when implementing institutional reform. Transition experience confirms several factors as essential for institutional change: the existing belief system and its evolution, trust and culture. In postsocialist societies, the prevailing culture is considered to be the main cause of increased transaction costs of institutional restructuring" (Šimić Banović R. $(2015))^{34}$.

To achieve the success of reforms, we should find the courage to build institutional interaction, not only by mechanistic borrowing of institutions similar to the ones in the countries of consolidated democracy but also by creating our unique model.

For this purpose we will use the method of "philosophical combinatorics" (Eremenko A., Yakovlev D. (2019)) $)^{35}$ and the theory of political choice.

After the events of 2013 - 2014, political elites in Ukraine are constantly seeking the optimal balance of power, solving the dual problem of ensuring the country's defence and democratizing institutional interaction. The constant fluctuations of the political course hinder the solution of this problem (Bilaniuk L. (2017) $)^{36}$.

Society cannot keep up with responding adequately to the constitutional, institutional and socio-cultural reversals of the elites. This fact diminishes the level of solidarity, institutional support and legitimacy of the elites. Simultaneously, it has a negative impact on both the level of defence and the level of democratic reforms: "Ethno-linguistic and regional identity became quite politicized during the 2004 presidential election. From then until 2014,

${ }^{34}$ Šimić Banović R. (2015). Institutional Interaction in the Business Environment: Eastern European Versus Western European Countries. Zbornik Pravnog fakulteta u Zagrebu, vol. 65, no. 3-4, pp. 439-480.

${ }^{35}$ Eremenko A., Yakovlev D. (2019) "My dialektiku uchili ne po Gegelyu". Filosofiya v zerkale politicheskoy propagandy: popytka antropologicheskogo podkhoda ["We studied dialectics not according to Hegel". The philosophy in the mirror of political propaganda: an attempt to the anthropological approach] Current problems of philosophy and sociology, no. 24, pp. 10-23.

36 Bilaniuk L. (2016). Ideologies of Language in Wartime. Revolution and War in Contemporary Ukraine: The Challenge of Change. Boston: AST, pp. 139-160 
political parties often used the "language issue" and the regional division for their purposes of mobilizing the electorate. This short-sighted practice has reduced solidarity in Ukrainian society. In the spring of 2014, linguistic and ethno-cultural issues were used not only for political purposes but also to substantiate the idea of separating the south-eastern regions of Ukraine (the so-called "Novorosiia"). However, the war that began after the separatist revolt mobilized both Ukrainian and Russian-speaking groups of the population to defend the country. The population of Ukraine consistently supported Ukrainian independence and sovereignty in all regions. Instead, some aspects of state ideological and ethno-linguistic policy were destroying this national solidarity. The implementation of "decommunization" laws has contributed to increasing distrust between the centre and local communities. Language quotas in the Ukrainian media and attempts to ban several social networking sites (that were proclaimed Russian) could heighten tensions between Ukrainian-speaking and Russian-speaking citizens. Finally, in 2017, a law was passed whereby all secondary schools with Russian language teaching, which as early as 2017 accounted for $9 \%$, were to be abolished" ${ }^{37}$.

The combinatorics of political choice makes it possible to move from hybrid models of institutional interaction (the sources for the creation of which can be found in the Soviet period) to their dialectical synthesis. Nowadays, the combinatorics of political choice should be aimed at tackling the difficult task of improving the effectiveness of institutional interaction in order to ensure defence in a democratic environment.

That is, "... Ukrainian society needs to solve the problem of synthesis of "institutes of peace and economic growth" (political and economic freedoms, free media, information pluralism, decentralization, etc.) with institutions that contribute to the country's defence capabilities (army, power structures, political and administrative hierarchy, etc.) ... in political space, there is a clash of political institutions and relations of democracy that are gaining weight and the remnants of political practices from the Soviet past, to which some citizens got accustomed ... at the present stage of democratization, an important political problem of optimal interaction of those political institutions that appeared at different stages of democratization in Ukraine under different conditions is actualized" 38 .

37 Minakov M. (2019) Postup demokratiji v Ukrajini (1991-2019) [The progress of democracy in Ukraine] SG Sofia website. Retrieved from: http://sg-sofia.com.ua/postupdemokratii-v-ukraini-1991-2019

38 Yakovlev D.V. (2019) Ljudyna i reformy: Kombinaciji vyboru [Man and reforms: A combination of choice] Proceedings of the Ljudyna maje pravo: socialjno-ghumanitarnyj dyskurs u konteksti reformacijnykh procesiv $v$ Ukrajini : materialy krughlogho stolu (Ukraine, Odesa, November 21, 2019) (eds. C. O. Kuznichenko, O. J. Nadybsjka), Odesa : Astroprynt. 
In order to increase the defence capability in a democratic environment, it is necessary to rationalize the institutional interaction between the institutions of the parliament, the government and the president, and opt for one of the electoral systems. Regarding the last point, at least two consecutive election campaigns should take place without significant changes to the electoral model. Voters have to get accustomed to the current political rules and regulations. This research deals with institutional interaction. However, its basis is a political choice. We use it to promote the public recognition that at the heart of all political processes is an individual. He/she evaluates, expects, rationalizes, chooses, and makes choices. A person should be at the centre of all transformations - this is mainly what the theory of choice says. Only "Homo eligit" is capable of generating rational combinations of political choices that will, as a result, provide an optimal model of institutional interaction as a factor in improving Ukraine's defence capacity in the conditions of democracy. It should be noted that, from the point of view of interdisciplinary research, attention is paid to the question: "How was consolidated democracy built in the countries of Western and Northern Europe in the aftermath of World War II?" Instead, we believe that this experience could be useful for Ukraine until 2014, that is, the beginning of the annexation of Crimea and the armed conflict in Eastern Ukraine. Nowadays, we have to look for other examples. The combinatorics of choice in the conditions of the armed conflict is required. Israel, Croatia, Georgia, Moldova should be noted among those countries that were forced to make democratic transit in the face of armed conflicts. They were simultaneously the parties to armed conflicts and were implementing democratic transit. The experience of only the post-Soviet countries (Georgia and Moldova) shows significant difficulties in this process. Rather, they, like Ukraine, embarked on the path of institutional reversals, authoritarian and oligarchic turns, and failed to escape the trap of "hybridity". "Georgia, Moldova and Ukraine are three participating states of the European Partnership that have chosen to conclude Association Agreements with the European Union, often at the expense of relations with their most powerful neighbour, Russia. They are also rather similar in their levels of democratic development. Within a post-Soviet space, they stand out for their relatively high level of democratic freedoms and political pluralism; none of them, however, can be considered a consolidated democracy, and most analysts describe them as uncertain or hybrid political regimes that combine features of autocracy and democracy"39.

\footnotetext{
${ }^{39}$ Ghia N., Cenusa D., Minakov M. (2017) Democracy and its Deficits: The Way of Georgia, Moldova and Ukraine towards Becoming European-Style Democracies. Center for European Policy Studies policy papers. Retrieved from: http://www.3dcftas.eu/publications/other/ democracy-and-its-deficitsway-georgia- moldova-and-ukraine-towards-becoming
} 
During the years of democratic transit (with several authoritarian reversals), political institutions had to adjust to either the "super-presidential" or the presidential-parliamentary and the parliamentary-presidential models of the distribution of powers of state, without taking into account the whole set of political institutions and identifying an optimal method of their interaction by the method of combinatorics.

Political actors who have received credibility from the society following the regular presidential and early parliamentary elections are at a crossroads nowadays: they have to choose a model of institutional interaction that will allow them to go through another election cycle. Therefore, the problem of researching the political and legal implementation of an optimal model of institutional interaction as a factor in improving Ukraine's defence capability in the context of democratization using an interdisciplinary approach is extremely important.

Studies of institutional interaction in transit countries, which at the same time need to enhance defence capabilities, will help to understand that political institutions are the result of deliberate rational actions in a changing social environment. This means that the search for an optimal model of institutional interaction as a factor in improving Ukraine's defence capability in the context of democratization requires rational planning and choosing appropriate legal conditions and political institutions.

\section{CONCLUSIONS}

Ukraine may become one of the first examples of a successful transition from authoritarianism and post-communist hybridity to democracy through institutional interaction. The role of the social sciences in achieving this ambitious goal is extremely important.

Firstly, it is necessary to offer a model of individual and collective behaviour for society at the crossroads. This model might be "Homo eligit". It is about interpreting the political process as a series of situations of choice between democracy and authoritarianism, presidential "vertical" and parliamentarism, proportional and majoritarian electoral systems, etc.

Secondly, the social sciences can offer an algorithm of action for an individual in the situation of choice. It is suggested to use the following alternatives to investigate the situation of choice: 1) Individualism vs. Collectivism; 2) Action vs. Structure; 3) Hierarchy vs. Network; 4) Stability vs. Conflict; 5) Rationality vs. Irrationality. Choosing one of the alternatives will allow forming a sound scientific assessment of individual's behaviour in every situation of choice and determine its orientation either on the continuation of "hybridity" policy or on democracy. 
Thirdly, the error in the study of individual institutions under conditions of democratic transit is identified. The success of democratization in the context of the need to improve defence depends on institutional interaction. The problem is not in the presence or absence of democratic institutions but in their interaction. It is only possible to determine the effectiveness of institutional interaction on the basis of a multidisciplinary approach. Using the method of combinatorics allows separating optimally balanced models of organization of power from unbalanced ones, justifying the correlation of the institutions of power with the given process of democratization, the potentials and properties of these institutions in the societies of consolidated democracy, which were solving simultaneously the task of reforming and enhancing defence capabilities.

Overall, the rational political choice of institutions and their combinatorics will allow overcoming the permanent instability of parliamentary institutions, the relative weakness of the party system, the instability of parliamentary coalitions, the closure of the electoral system, preventing government crises and ensuring the democratic rotation of the political elite.

\section{SUMMARY}

The article is devoted to the role of the social sciences in the process of institutional interaction and political choice. It is determined that the mission of the social sciences in a transitive society is to promote the rational choice of an individual. The model of research of a situation of choice on an example of institutional interaction in Ukraine is offered. The method of philosophical combinatorics and the method of choosing from several alternatives are used. This model includes the choice between authoritarianism and democracy, presidential and parliamentary forms of government, proportional and majoritarian electoral systems. In the social sciences, the combinatorics of the research programme on institutional interaction implies the choice between the alternatives: 1) Individualism vs. Collectivism; 2) Action vs. Structure; 3) Hierarchy vs. Network; 4) Stability vs. Conflict; 5) Rationality vs. Irrationality. Choosing one of the alternatives will allow forming a sound scientific assessment of individual's behaviour in every situation of choice and determine its orientation either on the continuation of "hybridity" policy or on democracy. 


\section{REFERENCES}

1. Bilaniuk L. (2016). Ideologies of Language in Wartime. Revolution and War in Contemporary Ukraine: The Challenge of Change. Boston: AST, pp. 139-160.

2. Clement J. (2016). Electoral rule choice in transitional economies. Journal of Institutional Economics, vol. 12, no. 4, pp. 895-919.

3. Conquest R. (2001). Reflections on a ravaged century. New YorkLondon: WW Norton \& Company

4. De Soto H. (2000). The mystery of capital: Why capitalism triumphs in the West and fails everywhere else. Bantam Press

5. Eremenko A., Yakovlev D. (2019) "My dialektiku uchili ne po Gegelyu". Filosofiya v zerkale politicheskoy propagandy: popytka antropologicheskogo podkhoda ["We studied dialectics not according to Hegel". The philosophy in the mirror of political propaganda: an attempt to the anthropological approach] Current problems of philosophy and sociology, no.24, pp. 10-23.

6. Ghia N., Cenusa D., Minakov M. (2017) Democracy and its Deficits: The Way of Georgia, Moldova and Ukraine towards Becoming EuropeanStyle Democracies. Center for European Policy Studies policy papers. Retrieved from:http://www.3dcftas.eu/publications/other/democracy-and-itsdeficitsway-georgia-moldova-and-ukraine-towards-becoming (accessed online 29 December 2019).

7. Gilbert A. (2002) On the mystery of capital and myths of Hernando de Soto: what difference does the legal title make? International Development Planning Review, № 24 (1), pp. 1-19.

8. Golovakha E., Panina N., Vorona V. (Eds) (2000) Sociology in Ukraine. Selected Works Published During 90-th. Kiev: Institute of Sociology

9. Hodgson G. (2001). How Economics Forgot History. London: Routledge.

10. Jay J. (2019). Education or Indoctrination. Discerning the Difference. Free Book site. Retrieved from: https://islidedocs.com/document/educationor-indoctrination-discerning-the-differencefree-book (accessed 25 May 2019).

11. Kroytor A., Yakovlev D., Aleksentseva-Timchenko K. (2019) 'Apostles' of indoctrination: ideological peculiarities of representation of religious choice in the secondary education (based on analysis of expert interviews) Ideology and Politics, no. 2 (13), pp. 127-146. Retrieved from: https://ideopol.org/wpcontent/uploads/2019/12/ (accessed online 31 December 2019).

12. Kulyk V. (2011) "Language Identity, Linguistic Diversity, and Political Cleavages: Evidence from Ukraine." Nations and Nationalism, vol. 17 no. 3 , pp. 627-648. 
13. Kuzio T. (1996) "National Identity in Independent Ukraine: An Identity in Transition. Nationalism and Ethnic Politics, vol. 2 no. 4, pp. 582-608.

14. Kuzio T. (2017) Putin's war against Ukraine. Revolution, nationalism, and Crime. Toronto: Association with the Chair of Ukrainian Studies, University of Toronto

15. Matsiyevsky Y. (2018) Revolution without Regime Change: The Evidence from the PostEuromaidan Ukraine. Communist and Post-Communist Studies, vol.51 no 4, pp. 349-359.

16. Minakov M. (2019) Postup demokratiji v Ukrajini (1991 - 2019) [The progress of democracy in Ukraine] SG Sofia website. Retrieved from: http://sg-sofia.com.ua/postup-demokratii-v-ukraini-1991-2019 (accessed online January 26, 2020)

17. Mitrokhin N. (2015) “Infiltration, Instruction, Invasion: Russia's War in the Donbass". Journal of Soviet and Post-Soviet Politics and Society, vol. 1 , no. 1 , pp. 219-49

18. Motyl A. J. (2001). Imperial ends: the decay, collapse, and revival of empires. New York: Columbia University Press

19. Rabkin Y., Minakov M. (eds.) (2018). Demodernization: A Future in the Past. Stuttgart: Verlag

20. Raišienè A., Bilan S., Smalskys V., Gečienè J. (2019). Emerging changes in attitudes to inter-institutional collaboration: the case of organizations providing social services in communities. Administratie si Management Public, no. 33, pp. 34-56.

21. Ramseyer J. M. (1995) Public Choice. Coase-Sandor Institute for Law \& Economics Working Paper, no. 34. Retrieved from: https://chicagounbound.uchicago.edu/cgi/viewcontent.cgi?article=1393\&cont ext=law_and_economics (accessed online January 20, 2020)

22. Riabchuk M. (1992) “Two Ukraines?”. East European Reporter, vol. 5, no. 4, pp. 18-22.

23. Riabchuk M. (2002) Ukraine: One State, Two Countries. Transit Online. Retrieved from: http://www.eurozine.com/pdf/2002-09-16-riabchuken.pdf. (accessed online 29 December 2019).

24. Riabchuk M. (2015) "Two Ukraine's' Reconsidered" The End of Ukrainian Ambivalence? Studies in Ethnicity and Nationalism, vol. 15, no. 1, pp. 138-156.

25. Šimić Banović, R. (2015). Institutional Interaction in the Business Environment: Eastern European Versus Western European Countries. Zbornik Pravnog fakulteta u Zagrebu, vol. 65, no. 3-4, pp. 439-480

26. Stefes C. H. (2006) Understanding Post-Soviet Transitions. London: Palgrave Macmillan. 
27. Udehn L. (2002). The Changing Face of Methodological Individualism. Annual Review of Sociology, no. 28, pp. 479-507. Retrieved from: www.jstor.org/stable/3069250. (accessed online January 26, 2020).

28. Walker E. W. (2014) "Ukraine: Divided Nation, Divided State. Eurasian Geopolitics. Retrieved from: http://eurasiangeopolitics.com/ 2014/03/14/ukraine-divided-nation-divided-state (accessed online 29 December 2019).

29. Wilson A. (2015). Can Ukraine Save Its Revolution? Current History, vol.114 no. 774, pp. 259-269.

30. Yakovlev D. (2015) Democracy "On the March": Rethinking the Role of Propaganda and the "Party of Power" under Armed Threat. Proceedings of the Scope: science of politics - International Interdisciplinary Conference of Political Research (Bucharest, May 8-9, 2015), University of Bucharest

31. Yakovlev D. (2015) Political choice of Ukraine: alternatives to the Grand Duke and restriction of the last secretary general. Proceedings of the Social and political configurations of Modernity: Political Power in Ukraine and in the World: Materials of the 4th International Scientific and Practical Conference (Ukraine Kyiv, June 3-4, 2015) (eds G. Derlugyan, A.A. Melnichenko, P.V. Kutuev, A.A. Migalush), Kyiv: Talcom, pp. 39-41.

32. Yakovlev D.V. (2015) Alea jacta est: vybir jak element socialjnoji vzajemodiji [Alea jacta est: choice as an element of modern interaction] Proceedings of the Priorytetni naprjamky rozvytku suspiljnykh nauk $u$ 21 stolitti": materialy mizhnarodnoji naukovoji konferenciji (Ukraine, Kherson, February 27-28, 2015), Kherson: Gheljvetyka, pp. 155-159.

33. Yakovlev D.V. (2016) Dylemy vyboru. [Dilemmas of choice]. Young scientist, vol. 7, no. 34, pp. 503-508. Retrieved from: http://molodyvcheny.in.ua/files/journal/2016/7/120.pdf (accessed online January 26, 2020).

34. Yakovlev D.V. (2016) Parlament na rozdorizhzhi: Rada jak instytut politychnogho vyboru [Parliament at the Crossroads: The Council as an Institute of Political Choice] Proceedings of the Parlamentsjki chytannja : 6-ta shhorichn. mizhnar. konfer. (Ukraine, Kyiv, November 18-19, 2016), Kyiv: FOP Zhorin R. V., pp. 12-17.

35. Yakovlev D.V. (2017) Ideja vyboru [The idea of choice ]. Proceedings of the Reghionaljna polityka : istorija, polityko-pravovi zasady, arkhitektura, urbanistyka: Tretja mizhnarnarodna naukovo-praktychna konferancija (Ukraine, Kyiv, November 22-23, 2017), Kyiv: Kyjiv. nac. un-t budivn. i arkhit-ry ta in, vol. 1, pp. 43-48.

36. Yakovlev D.V.(2019) Ljudyna i reformy: Kombinaciji vyboru [Man and reforms: A combination of choice] Proceedings of the Ljudyna maje pravo: socialjno-ghumanitarnyj dyskurs u konteksti reformacijnykh procesiv $v$ 
Ukrajini : materialy krughlogho stolu (Ukraine, Odesa, November 21, 2019) (eds. C.O. Kuznichenko, O.J. Nadybsjka), Odesa : Astroprynt.

37. Young A. (2017) Democratic Dialogue and the Constitution. New York: Oxford University Press

\section{Information about the authors:}

Denys Yakovlev, Prof. dr hab., Dean of the Faculty of Psychology, Political Science and Sociology, National University Odessa Law Academy 23, Fontanska str., Odessa, Ukraine ORCID ID: orcid.org/0000-0003-2828-4669

Liliya Yakovleva, $\mathrm{PhD}$, Associate Professor, Doctoral Student of the Department of Regional Policy and Public Administration, ORIPA NAPA under the President of Ukraine 22, Genuezka str., Odesa, Ukraine ORCID ID: orcid.org/0000-0002-0942-485X 